\title{
Propagação in vitro de sacaca (Croton cajucara Benth.): entendimentos sobre a dificuldade no desenvolvimento de protocolos de micropropagação da espécie
}

\author{
Tatiane Loureiro da Silva ${ }^{1}$ \\ Maria Aparecida Alves Pereira ${ }^{2}$ \\ Jonny Everson Scherwinski-Pereira ${ }^{3 *}$ \\ ${ }^{1}$ Instituto Federal de Educação, Ciência e Tecnologia do Acre, Campus de Xapuri \\ Rua Coronel Brandão, 1622, CEP 69.930-000, Xapuri - AC \\ ${ }^{2}$ Universidade Federal do Acre, Centro de Ciências Biológicas e da Natureza Campus Universitário \\ BR-364, km 04, CEP 69.920-900, Rio Branco - AC, Brasil \\ ${ }^{3}$ EMBRAPA Recursos Genéticos e Biotecnologia \\ Avenida W5 Norte (final), Parque Estação Biológica, CEP 70770-917, Brasília - DF, Brasil \\ * Autor para correspondência \\ jonny.pereira@embrapa.br
}

Submetido em 25/03/2015

Aceito em 25/09/2015

\section{Resumo}

A sacaca é uma planta medicinal do bioma Amazônico e tem sido considerada como substituta do pau-rosa (Aniba rosaeodora) na produção de linalol. Este trabalho objetivou avaliar a propagação vegetativa in vitro de sacaca, incluindo o estabelecimento de propágulos do campo, protocolos de descontaminação e a determinação de taxas de multiplicação, além de descrever aspectos limitantes da cultura durante os trabalhos in vitro. Foram utilizadas microestacas de $1,0 \mathrm{~cm}$, com uma gema axilar, coletadas de plantas adultas do campo. Tratamentos de desinfestação foram testados no estabelecimento, além de se avaliar a influência do mês do ano da coleta sobre as taxas de contaminação. Após desinfestadas, as microestacas foram inoculadas em tubos de ensaio com meio MS, suplementado com BAP $\left(0,1,2\right.$ e $\left.3 \mathrm{mg} \mathrm{L}^{-1}\right) \mathrm{e} \mathrm{AG}_{3}\left(0\right.$ e $\left.0,5 \mathrm{mg} \mathrm{L}^{-1}\right)$. Foi obtido o estabelecimento in vitro da sacaca com $41,9 \%$ das microestacas brotadas. A taxa de contaminação alcançou 58,1\% (65,4\% de origem fúngica e 34,6\% de origem bacteriana), com maior ocorrência quando os propágulos foram coletados entre os meses de outubro e janeiro, os mais chuvosos da região amazônica. $\mathrm{O}$ aumento nas concentrações de $\mathrm{BAP}$ e $\mathrm{AG}_{3}$ no meio de cultura melhorou as taxas de multiplicação do material. Apesar dos resultados obtidos, a espécie apresenta uma série de peculiaridades e limitações ao cultivo in vitro que foram identificadas e relatadas neste trabalho.

Palavras-chave: Amazônia; Croton spp.; Contaminação microbiana; Linalol; Plantas medicinais;

Organogênese

\section{Abstract}

In vitro propagation of sacaca (Croton cajucara): insights about difficulties for developing micropropagation protocols. Sacaca is a medicinal plant from the Amazonian biome and it has been regarded as a substitute for rosewood (Aniba rosaeodora) to produce linalool. This paper aimed to evaluate in vitro vegetative propagation of sacaca, including the establishment of propagules from the field, decontamination 
protocols, and determination of multiplication rates, besides describing limiting aspects for the culture during in vitro experiments. We used $1.0 \mathrm{~cm}$ microcuttings with an axillary bud, collected from adult plants in the field. Disinfestation treatments were tested in the establishment, and there is an evaluation of the collecting month influence on the contamination rates. After disinfestation, microcuttings were placed in test tubes containing MS medium, added with BAP $\left(0,1,2\right.$ and $\left.3 \mathrm{mg} \mathrm{L}^{-1}\right)$ and $\mathrm{GA}_{3}\left(0\right.$ and $\left.0.5 \mathrm{mg} \mathrm{L}^{-1}\right)$. In vitro establishment of sacaca with $41.9 \%$ of sprouted microcuttings was obtained. The contamination rate reached $58.1 \%(65.4 \%$ caused by fungi and $34.6 \%$ by bacteria), with greater occurrence when propagules were collected between October and January, the rainiest months in the Amazon region. The increased BAP and GA concentrations in the culture medium provided significant improvements in the material multiplication rates. In spite of the results obtained, the species shows peculiarities and limitations to in vitro cultivation that were identified and described in this paper.

Key words: Amazon; Linalool; Medicinal plants; Microbial contamination; Organogenesis

\section{Introdução}

Por caracterizar-se como um dos países possuidores da maior biodiversidade do planeta, abrigando inúmeras plantas detentoras de propriedades medicinais, aromáticas e princípios ativos de usos ainda não identificados, o Brasil e a Região Amazônica em particular, apresentam carência de resultados de pesquisa, especialmente na área agronômica de plantas aromáticas e medicinais nativas da região (LEWINSOHN; PRADO, 2002).

Muitas dessas espécies aromáticas ocorrem em ecossistemas diversos e estão sob forte pressão ambiental face à ação antropogênica, seja pela má exploração dos recursos florestais, ou pelos desmatamentos e queimadas produzidos pelo próprio desenvolvimento. Isso significa dizer que é urgente a iniciativa de se conhecer melhor a relação dessas espécies com o ambiente para se manejar corretamente, promover sua exploração ecologicamente correta e, por conseguinte, sua exploração econômica (CALIXTO, 2000).

Entre os diversos exemplos de substâncias oriundas de plantas, podem-se mencionar as obtidas de Croton cajucara, vulgarmente conhecida como sacaca. A sacaca foi sugerida como um substituto do pau-rosa (Aniba roseada), em vias de extinção, pois é produtora do linalol, um isolado aromático com potencial econômico de interesse para as indústrias de perfumarias, cosméticos e de produtos de limpeza. Além do linalol, a sacaca produz pineno, sabineno, estragol, linearisina e magnoflorina, princípios ativos destinados às indústrias de produtos farmacêuticos (SILVA et al., 2012; AZEVEDO et al., 2013). Na medicina, popular, o chá das folhas ou da casca é usado para distúrbios hepáticos e renais, além de reduzir o colesterol e a taxa de açúcar dos diabéticos (MACIEL et al., 2002; COSTA et al., 2007). No entanto, mesmo de uso consagrado pelas populações locais, os trabalhos fitotécnicos com a sacaca ainda são incipientes e sobre a propagação in vitro não se encontram dados na literatura. A sacaca multiplica-se precariamente por rebentos de raízes, sendo que a reprodução por via sexual é problemática por produzir baixos índices de sementes férteis (KALIL FILHO et al., 1998).

A técnica de multiplicação vegetativa mais usada para a clonagem de plantas lenhosas tem sido a estaquia que, embora seja utilizada com sucesso em várias espécies, para outras, pode apresentar resultados insatisfatórios (ASSIS; TEIXEIRA, 1998). Diante disso, a cultura de tecidos tem se apresentado como uma alternativa para a clonagem de espécies lenhosas. Muito mais que a possibilidade de se multiplicar em escala geométrica e em ciclos relativamente curtos, grande número de plantas a partir de um único explante, a cultura de tecidos é uma ferramenta pela qual se pode obter preciosas informações que facilitam o entendimento de espécies, seja no aspecto fisiológico, bioquímico ou molecular (MARIMUTHU; KUMAR, 2001; SUSSEX, 2008).

Particularmente para a sacaca, o início de estudos da espécie sob condições in vitro parece de fundamental importância, pois pode resultar, num futuro próximo, o melhor entendimento dos produtos do metabolismo secundário da planta e, consequentemente, o aproveitamento biotecnológico mais eficiente da espécie.

Em razão da importância da sacaca como planta 
aromática e medicinal e da deficiência de estudos que proporcionem um melhor conhecimento da espécie, esse trabalho teve como objetivo avaliar a propagação vegetativa in vitro de sacaca, incluindo o estabelecimento de materiais propagativos de plantas do campo, o desenvolvimento de protocolos de descontaminação, a estimação de taxas de multiplicação, além de indicar e descrever aspectos limitantes do cultivo in vitro da espécie.

\section{Material e Métodos}

O material propagativo utilizado nos experimentos in vitro foi proveniente de material vegetal obtido de brotações apicais coletadas de plantas adultas de sacaca em condições de campo, localizadas em latitude $10^{\circ} 00$ '53'S e longitude 67\%43'07'GRW, a partir de 2004.

Uma vez colhidos, os ramos (5 a $10 \mathrm{~cm}$ de comprimento) foram envoltos em papel toalha umedecido e levados para o laboratório onde foram desfolhados e subdividido em microestacas de 0,8 a 1,0 cm com uma gema axilar.

Para o ensaio de estabelecimento in vitro dos materiais provenientes de plantas do campo, as microestacas foram submetida à desinfestação por imersão em álcool $70 \%$ por um minuto, 20 minutos em solução de hipoclorito de sódio $(\mathrm{NaOCl}) 50 \%$ ( $\mathrm{v} / \mathrm{v}$ produto comercial) e tríplice lavagem com água destilada e autoclavada. Em seguida, as microestacas tiveram cortadas as extremidades e foram colocadas individualmente em tubos de ensaio $(20 \times 150 \mathrm{~mm}) \mathrm{com}$ $10 \mathrm{~mL}$ de meio de cultura, formado pelos sais e vitaminas de MS (MURASHIGE; SKOOG, 1962), suplementado com diferentes concentrações de benzilaminopurina (BAP) $\left(0,1,2\right.$ e $\left.3 \mathrm{mg} \mathrm{L}^{-1}\right)$ e ácido giberélico $\left(\mathrm{AG}_{3}\right)(0$ e $\left.0,5 \mathrm{mg} \mathrm{L}^{-1}\right)$. $\mathrm{O} \mathrm{pH}$ do meio de cultura foi ajustado para $5,8 \pm 0,1$ antes da adição do solidificante ágar ( 7 g. $\left.\mathrm{L}^{-1}\right)$ (Merck, Darmstadt, Germany), sendo posteriormente autoclavado à $121^{\circ} \mathrm{C}$ por 15 minutos e $1,3 \mathrm{~atm}$ de pressão.

$\mathrm{Na}$ primeira semana, o cultivo foi mantido no escuro para minimizar possíveis problemas de oxidação dos explantes. Posteriormente, desenvolveu-se sob temperatura de $25 \pm 2{ }^{\circ} \mathrm{C}$, fotoperíodo de $16 \mathrm{~h}$ e radiação luminosa de $30 \mathrm{mmol} . \mathrm{m}^{-2} \mathrm{~s}^{-1}$ fornecida por lâmpadas fluorescentes brancas frias (Phillips, 40w).

Após quatro semanas de cultivo, foram avaliadas as seguintes variáveis: percentual de contaminação geral, contaminação fúngica, contaminação bacteriana, porcentagem de brotações desenvolvidas, altura das brotações, taxa de multiplicação e número de folhas formadas. O delineamento experimental utilizado foi inteiramente casualizado com cinco repetições por tratamento, sendo cada parcela composta por quatro tubos de ensaio com uma microestaca.

Em razão dos problemas de contaminação observados no estabelecimento, foi realizado um experimento visando avaliar protocolos de desinfestação do material proveniente do campo. Neste ensaio, as microestacas foram submetidas a oito protocolos de descontaminação, sendo que o tratamento testemunha passou apenas pelo processo de tríplice lavagem com água destilada e autoclavada e foi denominada de ' $\mathrm{T}_{0}$ '. Os demais tratamentos foram constituídos de acordo com a Tabela 1 .

TABELA 1: Tratamentos de desinfestação usados em microestacas de sacaca oriundas de plantas do campo visando o estabelecimento in vitro.

\section{Tratamentos de desinfestação}

álcool $70 \%$ por 1 minuto e hipoclorito de sódio

$\mathrm{T}_{1} \quad(\mathrm{NaOCl}) 1,25 \%(\mathrm{v} / \mathrm{v})$ por 15 minutos;

álcool $70 \%$ por 1 minuto e hipoclorito de cálcio -

$\mathrm{T}_{2} \mathrm{Ca}(\mathrm{OCl})_{2} 1 \%(\mathrm{p} / \mathrm{v})$ por 15 minutos;

álcool $70 \%$ por 2 minutos e $\mathrm{NaOCl} 1,25 \%$ (v/v) por

$\mathrm{T}_{3} 20$ minutos;

álcool $70 \%$ por 2 minutos e $\mathrm{Ca}(\mathrm{OCl})_{2} 1 \%(\mathrm{p} / \mathrm{v})$ por 20

4 minutos;

álcool $70 \%$ por 30 segundo, bicloreto de mercúrio

$\mathrm{T}_{5}\left(\mathrm{HgCl}_{2}\right) 0,25 \%(\mathrm{p} / \mathrm{v})$ por 10 minutos, álcool $70 \%$ por 30 segundo e $\mathrm{NaOCl} 1,25 \%$ (v/v) por 10 minutos; álcool $70 \%$ por 30 segundo, $\mathrm{HgCl}_{2} 0,25 \%(\mathrm{p} / \mathrm{v})$ por 10

$\mathrm{T}_{6}$ minutos, álcool $70 \%$ por 30 segundo e $\mathrm{Ca}(\mathrm{OCl})_{2} 1 \%$ (v/v) por 10 minutos;

T álcool 92\% por um minuto e $\mathrm{NaOCl} 50 \%(\mathrm{v} / \mathrm{v})$ por 15 $\mathrm{T}_{7}$ minutos.

Ao final de cada protocolo de desinfestação, as microestacas passaram por tríplice lavagem em água destilada e esterilizada e foram inoculadas, individualmente, em tubos de ensaio $(25 \times 150 \mathrm{~mm})$ 
com $5 \mathrm{~mL}$ de meio de cultura MS, solidificado com 5,0 g. $\mathrm{L}^{-1}$ de Agar. Os ajustes de $\mathrm{pH}$ e esterilização, além das condições de manutenção do material foram idênticos aos experimento de estabelecimento.

O delineamento experimental utilizado foi inteiramente casualizado com quatro repetições por tratamento. Cada parcela foi representada por cinco tubos de ensaio com uma microestaca. A avaliação do experimento quanto ao número de microestacas brotadas, altura das brotações, taxa de multiplicação, número de folhas por explantes e percentual de contaminação foi realizado quatro semanas após a instalação do experimento.

Para se determinar a melhor época para a coleta de material propagativo de sacaca em campo, por dois anos consecutivos entre os meses de agosto e janeiro, brotações apicais de sacaca foram coletadas sob condições de campo, e em laboratório foram desfolhadas e desinfestadas. O processo de desinfestação foi o mesmo utilizado no experimento de estabelecimento in vitro. As microestacas foram inoculadas em tubos de ensaio ( $20 \times 150 \mathrm{~mm}$ ) contendo $5 \mathrm{~mL}$ de meio de cultura de MS.

Durante 28 dias de cultivo, em intervalos de sete dias, foram avaliadas as seguintes variáveis: percentual de contaminação total, contaminação fúngica, contaminação bacteriana e porcentagem de brotações. $\mathrm{O}$ delineamento experimental utilizado foi em blocos ao acaso com cinco repetições. Cada parcela foi composta por oito tubos cada um contendo uma microestaca. Os ajustes de $\mathrm{pH}$ e esterilização, além das condições de manutenção do material foram idênticos em todos os experimentos.

Os contaminantes fúngicos e bacterianos foram isolados e submetidos à identificação por testes morfológicos e bioquímicos característicos. Os isolados fúngicos foram identificados no Laboratório de fitopatologia da Embrapa Acre, enquanto que os contaminantes bacterianos foram identificados pela Fundação André Tosello em Campinas, estado de São Paulo.

Os dados foram submetidos à análise de variância e de regressão, e as médias comparadas pelo teste de Duncan a $5 \%$ de probabilidade, com o auxílio do programa estatístico Sanest (ZONTA; MACHADO, 1984). Os dados expressos em percentagem (x) foram transformados segundo arco seno $\sqrt{x / 100}$ enquanto que para taxa de multiplicação (x) foram transformados segundo $\sqrt{x+0,5}$.

\section{Resultados e Discussão}

Apesar de para muitas espécies de plantas o $\mathrm{AG}_{3}$ promover a brotação e o crescimento (MADEIRA et al., 2005; VIDAL et al., 2013), neste trabalho, a adição de $\mathrm{AG}_{3}$ no meio de cultura não influenciou a brotação das microestacas de sacaca estabelecidas (Figura 1A). De maneira geral esses resultados também foram observados quando se avaliou a taxa de multiplicação do material estabelecido in vitro, com exceção da concentração de 3,0 $\mathrm{mg} \mathrm{L}^{-1}$ de BAP, onde a taxa multiplicação foi significativamente superior quando se usou $\mathrm{AG}_{3}$ quando comparado ao tratamento em que não se adicionou $\mathrm{AG}_{3}$ no meio de cultura, sugerindo que para ambas as variáveis avaliadas o efeito do BAP parece ter sido mais pronunciado do que a combinação com o $\mathrm{AG}_{3}$ (Figura 1B).

Assim, para percentagem de brotação, diferenças significativas só foram observadas para níveis de BAP, uma vez que $o$ aumento nas concentrações deste regulador proporcionou um comportamento ascendente na curva de regressão para esta variável até aproximadamente $1,8 \mathrm{mg} \mathrm{L}^{-1}$ de BAP, onde nesta concentração $58,9 \%$ das microestacas apresentaram brotação, após 30 dias de cultivo (ponto de máxima eficiência calculada). Após essa concentração, incrementos nos valores de BAP corresponderam à queda nas taxas de brotação (Figura 2). Nas concentrações 0 e $3 \mathrm{mg} \mathrm{L}^{-1}$ de BAP foi onde as microestacas apresentaram as menores taxas de brotação, com cerca de $30 \%$ dos explantes brotados, sugerindo que o BAP foi importante para promover a brotação das microestacas, embora em concentrações mais elevadas pode ser menos efetivo, tóxico ou ainda não ser a citocinina ideal para ao cultivo (FRÁGUAS et al., 2004).

Possivelmente, o efeito mais pronunciado das giberelinas in vitro seja o alongamento das partes aéreas (FIGUEIREDO et al., 2001). Mas de modo geral, para a sacaca as concentrações de $\mathrm{BAP}$ e $\mathrm{AG}_{3}$ testadas não proporcionaram diferenças significativas para altura 
das brotações desenvolvidas a partir das microestacas estabelecidas. Após 30 dias de cultivo as brotações apresentaram altura média de $0,6 \mathrm{~cm}$. No entanto, se os tratamentos com BAP e $\mathrm{AG}_{3}$ não apresentaram influência sobre altura de brotações, o aumento nas concentrações de BAP no meio de cultura, proporcionou acréscimos lineares na taxa de multiplicação do material estabelecido in vitro (Figura 1B). Assim, na concentração de $3,0 \mathrm{mg} \mathrm{L}^{-1}$ de BAP as taxas de multiplicação observadas em relação às concentrações 0 e $0,5 \mathrm{mg} \mathrm{L}^{-1}$ de $\mathrm{AG}_{3}$ foram de $2,8 \mathrm{e}$ 3,7 respectivamente, valores esses, significativamente diferentes (Figura 1A). Estes resultados confirmam o papel fundamental das citocininas na estimulação da divisão celular, bem como na indução e proliferação de gemas adventícias (RATHORE et al., 1992; PEREIRA et al., 1995).
Monfort et al. (2012) descrevem que a adição de BAP no meio de cultura foi determinante para o aumento do número de brotações em alfavaca (Ocimum selloi), uma planta medicinal. Em Crossandra infundibulisformis Nees, cv. Mona Wallhead, Almeida et al. (2009) também verificaram que o BAP foi significativamente superior quando comparado ao $2 \mathrm{iP}$ para maior acúmulo de brotações. Resultados benéficos semelhantes ao verificados acima, quanto ao efeito do BAP na multiplicação, também foi observado por Cordeiro et al. (2014) em Eucalyptus globulus que, de modo geral, verificaram que as melhores respostas quanto a proliferação de gemas axilares foram obtidas quando os explantes foram cultivados em meio nutritivo suplementado com 0,7 mg.L. $\mathrm{L}^{-1}$ de BAP.

FIGURA 1: Efeito de concentrações de $\mathrm{AG}_{3}$ em meio de cultura com BAP sobre a percentagem de explantes brotados durante o estabelecimento in vitro de microestacas (\%) de sacaca (A) e na taxa de multiplicação de brotos (B). Médias seguidas por letras idênticas dentro de cada concentração de BAP testada não diferem estatisticamente entre si pelo teste de Duncan a 5\% de probabilidade.

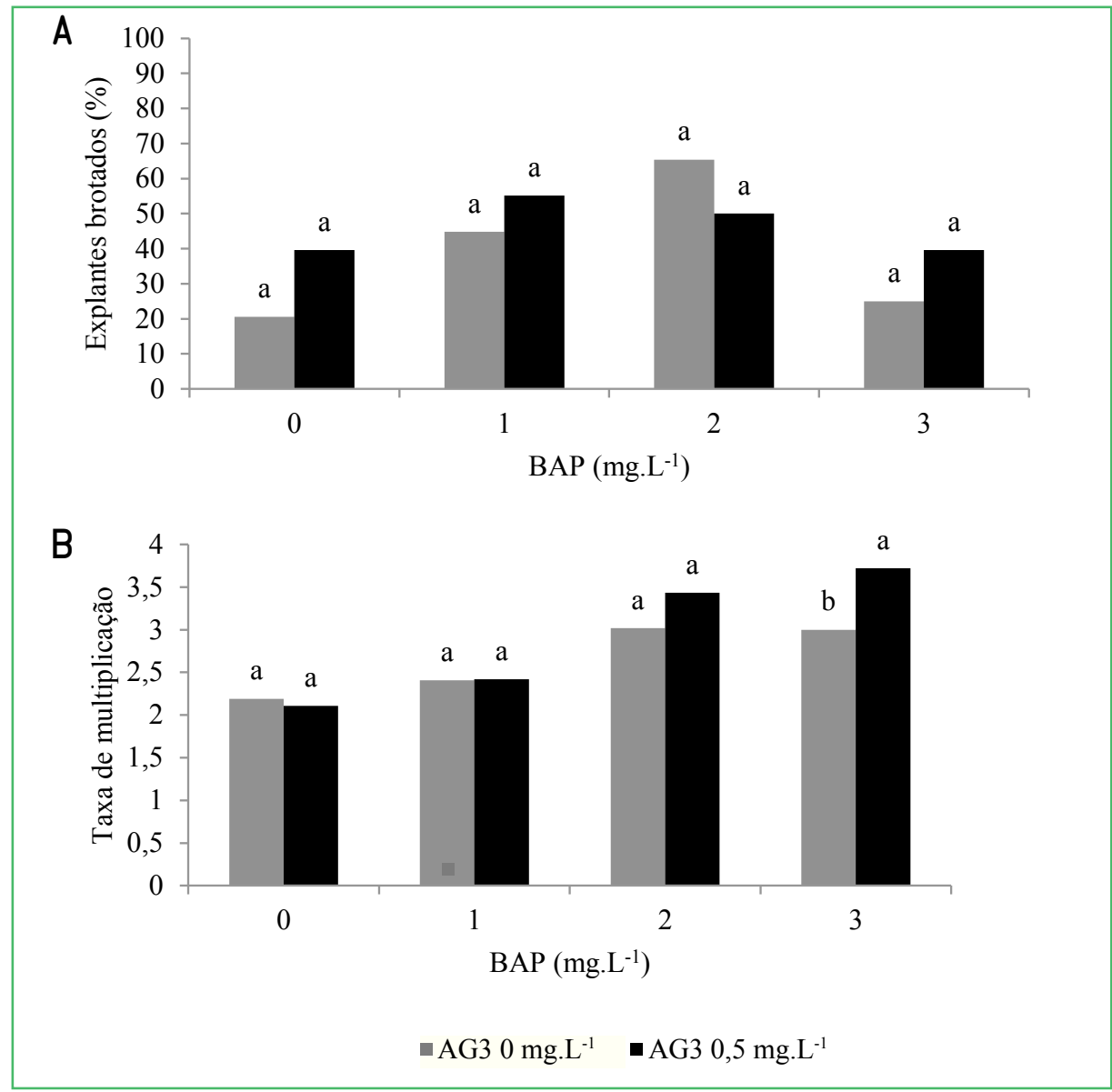


FIGURA 2: Brotação de microestacas de sacaca em resposta as diferentes concentrações de BAP no meio de cultura de MS e taxa de multiplicação de microestacas de sacaca em função das diferentes concentrações de $\mathrm{BAP}$ e $\mathrm{AG}_{3}$ no meio de cultura de MS.

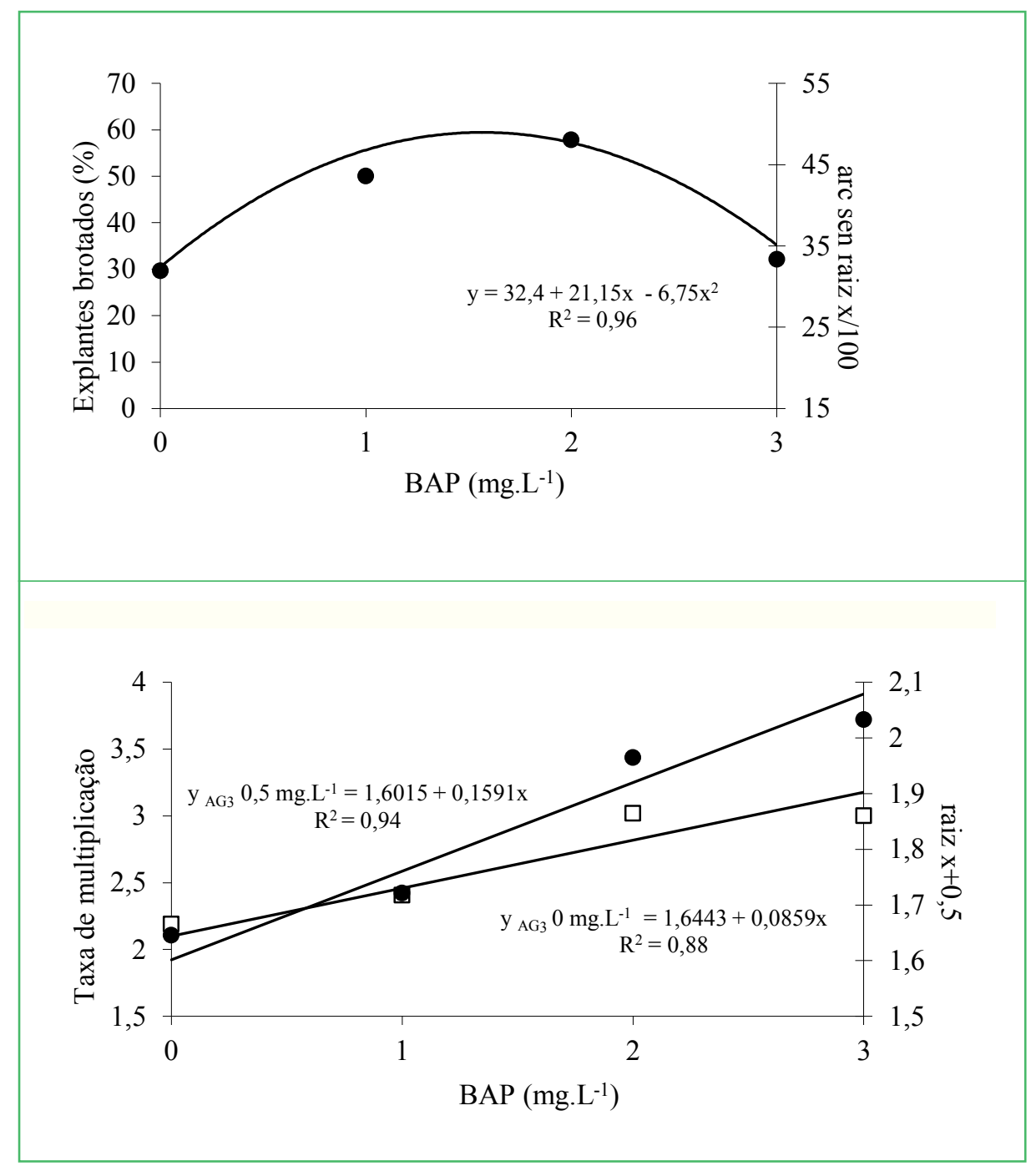

O estabelecimento in vitro da sacaca foi obtido com um percentual de $41,9 \%$ dos explantes brotados, sendo que a contaminação atingiu $58,1 \%$. Deste total, $65,4 \%$ foi ocasionada por fungos e $34,6 \%$ por bactérias. Apesar de não terem sido feito testes mais aprofundados, este alto índice de contaminação observado nos explantes são em grande parte devido a contaminantes endógenos aos tecidos de sacaca, uma vez que a sacaca pertence a família Euphorbiaceae, a mesma da seringueira, o que lhe confere a exsudação de um látex característico que provavelmente seja uma importante fonte de microrganismos (VARRICCHIO et al., 2008). Outro fator a considerar no cultivo da sacaca refere-se à superfície do material propagativo utilizado que apresenta grande quantidade de pêlos superficiais (dados não apresentados), característica que dificulta a completa exposição dos explantes aos agentes antimicrobianos. Contudo, de modo geral, a introdução de espécies diretamente do campo para condições de cultivo in vitro é reconhecidamente problemáticas em razão dos importantes problemas de contaminação provocados por fungos e bactérias (GRATTAPAGLIA; MACHADO, 1998; SCHERWINSKI-PEREIRA et al., 2003). Bianchi et al. (2003) verificaram que o tipo de explante influenciou significativamente a taxa de contaminação durante o estabelecimento do 
marmeleiro (Cydonia oblonga Mill.) e concluíram que meristemas são mais propícios para o estabelecimento por apresentarem menores taxas de contaminação total (36,0\%) quando comparado a segmentos nodais onde a contaminação atingiu $70,6 \%$ dos explantes. Oliveira e Silva (1997), trabalhando com o estabelecimento de bananeira, cv. Grand Naine, tiveram até 40,6\% dos explantes apresentando algum tipo de contaminação. Portanto, quando se avalia estes dados, verifica-se que os índices de descontaminação alcançados nos explantes de sacaca não foram demasiadamente diferentes aos obtidos por outros autores quando se trata de estabelecimento in vitro de material proveniente do campo.

Cerca de 30 dias após o estabelecimento, as brotações desenvolvidas começaram a apresentar a queda de folhas. Um dos primeiros trabalhos a relatar problemas de desfolhamento de plantas durante etapas da micropropagação foi o desenvolvido por Broome e Zimmerman (1984), que observaram que para algumas cultivares de macieira, após três a quatro semanas em cultura, as partes aéreas começavam a senescer até ocorrer a queda de folhas e o escurecimento da zona de abscisão do pecíolo. De acordo com Shukor et al. (2008), a desfolhação é um fenômeno comum em Azadirachta excelsa que geralmente impede a produção de mudas por micropropagação.
Assim, é possível que a queda de folhas observado nos explantes de sacaca possa estar relacionada ao tempo de subcultivos, que pode influenciar a condição ambiental dos cultivos de diferentes maneiras, especialmente quanto a produção ou acúmulo de etileno (PEREIRA-NETTO, 2001; PEREIRA-NETTO et al., 2003; SHUKOR et al., 2008; KUMAR et al., 2009). De fato, determinadas espécies não são tolerantes à dilatação do prazo do subcultivos, como relatado em Eucalyptus gunnii para o qual transferências a cada 15 a 21 dias foram necessárias para evitar a necrose apical e morte dos tecidos (BOULAY, 1984). Em mangaba (Hancornia speciosa), Sá et al. (2012) também determinaram um tempo ótimo para o subcultivo da espécie, uma vez que subcultivos de 65 dias promoveram mais intensamente a abscisão foliar de microbrotos, quando comparados àqueles subcultivados a cada 50 dias. Portanto, para determinadas espécies, sobretudo as lenhosas, as plantas in vitro ao entrarem em crescimento ativo, podem dentro de poucas semanas entrarem em fase de senescência e simplesmente pararem a multiplicação, com consequente queda das folhas. No entanto, verificou-se em sacaca que após a completa queda das folhas, houve a formação de um tecido celular superficial na quase totalidade dos explantes, a partir do qual, após aproximadamente um mês, novas multibrotações foram originadas (Figura 3).

FIGURA 3: Brotações de sacaca durante desenvolvimento in vitro: A) Aspecto de brotação de sacaca estabelecida in vitro; B) brotação apresentando queda de folhas; C) início da formação de tecido celular superficial na brotação, após queda das folhas; D) aspecto de brotação praticamente tomada por tecido celular superficial, após queda de folhas; E) aspecto de brotação em estádio de superbrotamento, após a fase de queda das folhas e formação de tecido celular superficial in vitro.
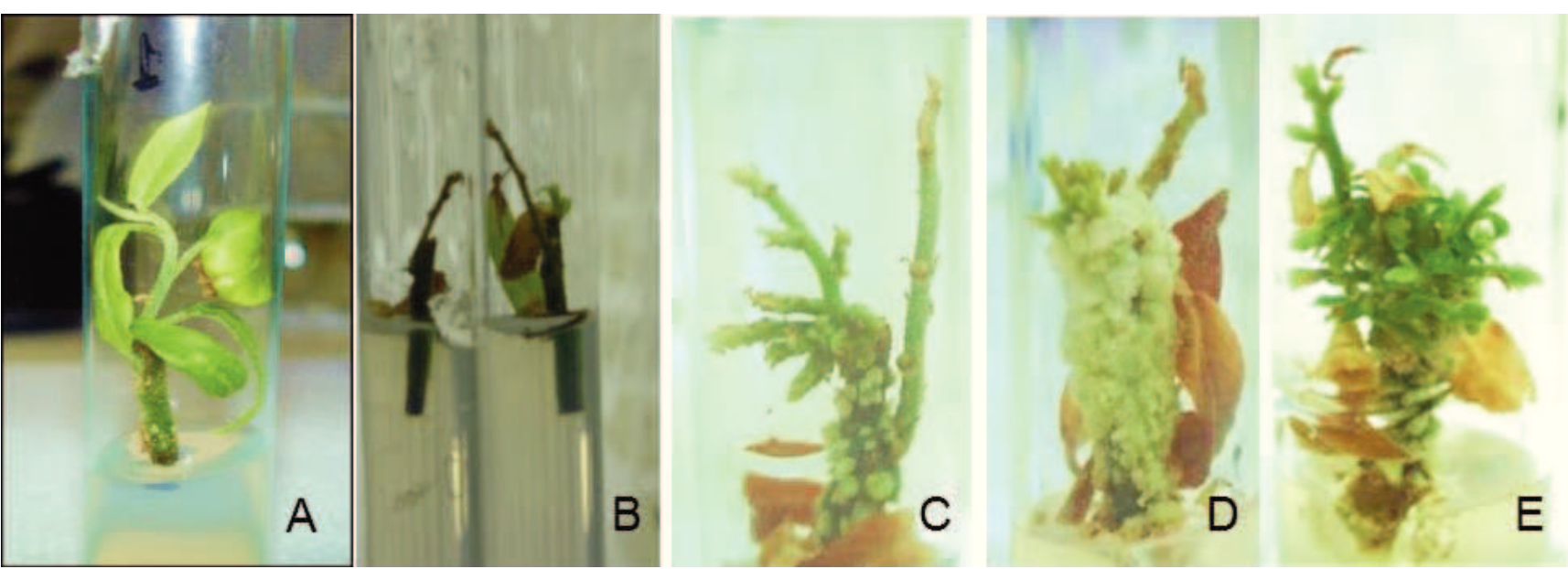
As contaminações representam um dos problemas de maior importância na fase de estabelecimento de materiais in vitro. $\mathrm{O}$ aparecimento de fungos e bactérias após alguns dias de cultivo, normalmente deve-se à presença endógena destes agentes no tecido, especialmente se todas as medidas preventivas visando a descontaminação inicial dos explantes tiverem sido tomadas (FORTES; PEREIRA, 2001; SCHERWINSKIPEREIRA et al., 2003). Por isso, um grande número de trabalhos tem sido realizado para descontaminação de explantes oriundas de plantas do campo (CALDAS; TAKETOMI, 1993; FORTES; PEREIRA, 2001; SATO et al., 2001; ABREU et al., 2003; ERIG et al., 2003). De modo geral, a desinfestação dos diversos segmentos da planta (brotos, microestacas, folhas, botões florais) é feita utilizando álcool etílico comercial na concentração de 50 a $70 \%$, por um período de 1 a 3 minutos, seguido de um tratamento com hipoclorito de sódio ou cálcio a 0,5 a $2 \%(\mathrm{p} / \mathrm{v})$ por 5 a 20 minutos, seguido de 3 a 5 lavagens com água destilada estéril. $\mathrm{O}$ uso de cloreto de mercúrio, embora mais raro devido a sua toxidez, também pode dar bons resultados, numa concentração de 0,05 a $0,2 \%(\mathrm{p} / \mathrm{v})$, por um período de 5 a 20 minutos, seguido de 3 a 5 lavagens com água destilada estéril. Neste trabalho, entre os tratamentos de desinfestação testados, os mais eficientes foram o 'T5' e 'T6' que proporcionaram um percentual de descontaminação de $50 \%$ dos explantes (Tabela 2), ambos que continham em seus protocolos a presença de $\mathrm{HgCl}_{2}$. Resultados positivos quanto a utilização de $\mathrm{HgCl}_{2}$ também são citados por Ribas et al. (2003) na desinfestação de Aspidosperma polyneuron em concentração de $0,05 \%$ e tempo de imersão de 10 minutos.

No entanto, quando avaliado o percentual de brotação dos explantes tratados com estes tratamentos, observou-se que as microestacas apresentaram percentuais de brotação de $30 \%$ e $50 \%$, respectivamente (dados não mostrados). Tais resultados possivelmente tenham ocorrido pela ação tóxica do $\mathrm{HgCl}_{2}$ uma vez que este tipo de substância, apesar de seu poder de desinfestação, apresenta elevada toxicidade a tecidos de plantas, potencializado pela ação do $\mathrm{NaOCl}$ já que como citado previamente, na comparação com o $\mathrm{Ca}(\mathrm{OCl})_{2}$ foi ainda mais tóxico no que diz respeito à capacidade de brotação das microestacas. Nos demais tratamentos, devido à elevada taxa de contaminação observada, não foi possível avaliar a porcentagem de explantes brotados.

TABELA 2: Percentual de contaminação de explantes de sacaca durante a avaliação de diferentes protocolos de desinfestação.

\begin{tabular}{|c|c|c|}
\hline \multicolumn{2}{|r|}{ Tratamentos } & $\begin{array}{c}\text { Contaminação } \\
(\%)^{* *}\end{array}$ \\
\hline T0 & $\begin{array}{l}3 \text { lavagem em água destilada e } \\
\text { autoclavada }\end{array}$ & $100 \mathrm{a}$ \\
\hline $\mathrm{T} 1$ & 1 min álcool $70 \%+15 \min \mathrm{NaOCl}^{*}$ & $94,7 \mathrm{ab}$ \\
\hline $\mathrm{T} 2$ & 1 min álcool $70 \%+15 \min \mathrm{Ca}(\mathrm{OCl})_{2}$ & $98,6 \mathrm{ab}$ \\
\hline $\mathrm{T} 3$ & 2 min álcool $70 \%+20 \min \mathrm{NaOCl}$ & $88,3 \mathrm{~b}$ \\
\hline T4 & 2 min álcool $70 \%+20 \min \mathrm{Ca}(\mathrm{OCl})_{2}$ & $100,0 \mathrm{a}$ \\
\hline T5 & $\begin{array}{l}30 \text { seg. álcool } 70 \%+10 \min \mathrm{HgCl}_{2} \\
0,25 \%+10 \operatorname{min~} \mathrm{NaOCl}\end{array}$ & $50,0 \mathrm{c}$ \\
\hline T6 & $\begin{array}{l}30 \text { seg. álcool } 70 \% \text { por }+10 \text { min } \\
\mathrm{HgCl}_{2} 0,25 \%+10 \mathrm{~min} \mathrm{Ca}(\mathrm{OCl})_{2}\end{array}$ & $50,0 \mathrm{c}$ \\
\hline $\mathrm{T} 7$ & 1 min álcool 92\% + $15 \min \mathrm{NaOCl})$ & $94,7 \mathrm{ab}$ \\
\hline C.V & & $16,4 \%$ \\
\hline
\end{tabular}

* após os tratamentos todo o material propagativo sofreu tríplice lavagem com água destilada e esterilizada. **Médias seguidas por letras minúsculas distintas na vertical e dentro de cada variável analisada, diferem entre si ao nível de $5 \%$ de probabilidade pelo teste Duncan.

Na avaliação da época do ano na coleta de materiais de sacaca em campo e estabelecimento in vitro, verificouse que de maneira geral, os meses de agosto e setembro apresentaram um índice menor de contaminações, assim como maior número de brotações desenvolvidas (Tabela 3). Este fato deve estar relacionado com o clima da região nesta época. A partir de outubro até janeiro, a contaminação é bastante elevada, principalmente a fúngica, o que leva a morte das microestacas. $\mathrm{Na}$ região Amazônica este período corresponde ao inverno Amazônico caracterizando-se pela grande ocorrência de chuvas, fato que pode influenciar no estabelecimento das microestacas. Os fungos isolados dos explantes de sacaca foram classificados como pertencentes aos gêneros Aspergillus spp., Penicillium spp. e Talaromyces flavus. Já as bactérias foram identificadas como pertencentes às espécies Bacillus cereus, Stenotrophomonas maltophilia e Brevundimonas vesicularis. 
TABELA 3: Avaliação da influência da época de coleta do material em campo no estabelecimento in vitro de sacaca.

\begin{tabular}{lcccc}
\hline \multirow{2}{*}{$\begin{array}{c}\text { Meses do } \\
\text { ano }\end{array}$} & \multicolumn{3}{c}{ Contaminação (\%)* } & \multirow{2}{*}{ Brotadas*** } \\
\cline { 2 - 4 } & Total & Bacteriana** & Fúngica** & \\
\hline Agosto & 76,5 & 45,8 & 54,2 & 39,3 \\
Setembro & 47,6 & 0,0 & $100 \mathrm{a}$ & 52,6 \\
Outubro & 99,7 & 3,5 & 96,5 & 0,0 \\
Novembro & 97,8 & 0,0 & $100 \mathrm{a}$ & 2,1 \\
Dezembro & 100 & 0,2 & 99,8 & 0,0 \\
Janeiro & 100 & 0,0 & 100 & 0,0 \\
\hline
\end{tabular}

* Média de dois anos consecutivos; ** Contaminação fúngica e bacteriana em relação ao percentual total de contaminação; *** em relação ao total inoculado e que não apresentando contaminação durante o período avaliado.

Este trabalho constitui-se num dos primeiros relatos sobre a tentativa de se propagar esta importante espécie medicinal in vitro. Com os resultados obtidos, conclui-se que o uso de microestacas com gema única constitui-se como um material promissor para o estabelecimento e multiplicação in vitro de sacaca e que a presença de 3,0 $\mathrm{mg} \mathrm{L}^{-1}$ de BAP e $0,5 \mathrm{mg} \mathrm{L}^{-1}$ de $\mathrm{AG}_{3}$ no meio de cultura de MS promove melhorias nas taxas de multiplicação in vitro da sacaca. A utilização de microestacas provenientes de brotações apicais de sacaca coletadas em campo apresenta elevada taxa de contaminação pela associação de microrganismos endofíticos aos tecidos, especialmente os fungos Aspergillus spp., Penicillium spp. e Talaromyces flavus e as bactérias Bacillus cereus, Stenotrophomonas maltophilia e Brevundimonas vesicularis. Os meses mais chuvosos do ano na Região Amazônica (outubro a janeiro) são os que proporcionam as maiores taxas de contaminação dos explantes no estabelecimento in vitro da sacaca.

\section{Agradecimentos}

Ao Conselho Nacional de Desenvolvimento Científico Tecnológicos - CNPq, pelas bolsas e apoio ao grupo de Pesquisa.

\section{Referências}

ABREU, I. N.; PINTO, J. E. B. P.; BERTOLUCCI, S. K. V.; MORAIS, A. R.; GEROMEL, C.; LADEIRA, A.; LAMEIRA, O. A. Propagação in vivo e in vitro de Cissus sicyoides, uma planta medicinal. Acta Amazonica, Manaus, v. 33, n. 1, p. 1-7, 2003.

ALMEIDA, J. L.; DINIZ, J. D. N.; HERNANDEZ, F. F. F. Micropropagação de Crossandra infundibuliformis Ness cultivar 'Mona Wallhead'. Revista Brasileira de Horticultura Ornamental, Campinas, v. 14, n. 2, p. 115- 122, 2009.

ASSIS, T. F.; TEIXEIRA, S. L. Enraizamento de plantas lenhosas. In: TORRES, C.; CALDAS, L. S.; BUSO, J. A. (Ed.). Cultura de tecidos e transformação genética de plantas. Brasília: EMBRAPA: SPI, 1998. p. 261-296.

AZEVEDO, M. M. B.; CHAVES, F. C. M.; ALMEIDA, C. A.; BIZZO, H. R.; DUARTE, R. S.; CAMPOS-TAKAKI, G. M.; ALVIANO, C. S.; ALVIANO, D. S. Antioxidant and antimicrobial activities of 7-hydroxycalamenene-rich essential oils from Croton cajucara Benth. Molecules, Basel, v. 18, p. 1128-1137, 2013.

BIANCHI, V. J.; CHAVES, A. C.; SCHUCH, M. W.; FACHINELLO, J. C. Estabelecimento in vitro de marmeleiro: efeito do tipo de explante e tempo de imersão em hipoclorito de sódio. Revista Brasileira de Agrociência, Pelotas, v. 9, n. 2, p. 177-179, 2003.

BOULAY, M. Aspects pratiques de la multiplication in vitro des essences forestieres. In: AFOCEL (Ed.). Annales de recherches sylvicoles. Paris: Association Foret-Cellulose, 1984. p. 7-4.

BROOME, O. C; ZIMMERMAN, R. H. Culture of shoot meristems: fruit plants. In: VASIL, I. K. (Ed.). Cell culture and somatic cell genetics of plants. Vol. 1. New York: Academic Press, 1984. p. 111-122.

CALDAS, L. S.; TAKETOMI, C. Desinfestação e controle de oxidação de explantes lenhosos de jabuticabeira e goiabeira para cultura de tecidos. Revista Brasileira de Fisiologia Vegetal, Campinas, v. 5, n. 1, p. 107, 1993.

CALIXTO, J. B. Biopirataria: a diversidade biológica na mira da indústria farmacêutica. Ciência Hoje, Rio de Janeiro, v. 28, n. 167, p. $36-43,2000$

CORDEIRO, G. M.; BRONDANI, G. E.; OLIVEIRA, L. S.; ALMEIDA, M. Meio de cultura, BAP e ANA na multiplicação in vitro de clones de Eucalyptus globulus Labill. Scientia Forestalis, Piracicaba, v. 42, n. 103, p. 337-344, 2014.

COSTA, M. P.; MAGAlhaES, N. S. S.; GOMES, F. E. S.; MACIEL, M. A. M. Uma revisão das atividades biológicas da trans-desidrocrotonina, um produto natural obtido de Croton cajucara. Revista Brasileira de Farmacognosia, Curitiba, v. 17, n. 2, p. 275-286, 2007.

ERIG, A. C.; VICENZI, M.; CHAVES, A. C.; SCHUCH, M. W.; FACHINELLO, J. C. Desinfestação de explantes de mirtilo (Vaccinium ashei Reade) visando o estabelecimento de plantas in vitro. Revista Científica Rural, Bagé, v. 8, n. 1, p. 142-148, 2003.

FIGUEIREDO, S. F. L.; ALBARELlO, N.; VIANA, V. R. C. Micropropagation of Rollinia mucosa (Jacq.) Baill. In vitro Cellular \& Development Biology - Plant, Gaitherburg, v. 37, n. 4, p. 471-475, 2001.

FORTES, G. R. L.; PEREIRA, J. E. S. Estabelecimento in vitro da ameixeira cv. América. Revista Brasileira de Fruticultura, Jaboticabal, v. 23, n. 1, p. 183-185, 2001.

FRÁGUAS, C. B.; PASQUAL, M.; PEREIRA, A. R. Multiplicação in vitro de Ficus carica L.: efeito da cinetina e do ácido giberélico. Ciência e Agrotecnologia, Lavras, v. 28, n. 1, p. 49-55, 2004.

GRATTAPAGLIA, D.; MACHADO, M. A. Micropropagação. In: TORRES, C.; CALDAS, L. S.; BUSO, J. A. (Ed.). Cultura 
de tecidos e transformação genética de plantas. Brasília: EMBRAPA: SPI, 1998. p. 183-260.

KALIL FILHO, A. N.; LUZ, A. I. R.; SÁ SOBRINHO, A. F. de; WOLTER, E. L. de A.; PEREIRA JUNIOR, O. L. Conservação de germoplasma de sacaca (Croton cajucara Benth.), uma nova fonte de linalol para a Amazônia Ocidental. Manaus: EMBRAPA Amazônia Ocidental, 1998. 3 p. (Pesquisa em Andamento, 39).

KUMAR, V.; PARVATAM, G.; RAVISHANKAR, G. $\mathrm{AgNO}_{3}$ - a potential regulator of ethylene activity and plant growth modulator. Electronic Journal of Biotechnology, Valparaíso, v. 12, n. 2, 2009. DOI: 10.2225/vol12-issue2-fulltext-1.

LEWINSOHN, T. M.; PRADO P. I. Biodiversidade brasileira: síntese do estado atual do conhecimento. São Paulo: Editora Contexto, 2002. 176 p.

MACIEL, M. A.; PINTO, A. C.; VEIGA JUNIOR, V. F.; GRYNBERG, N. F.; ECHEVARRIA, A. Plantas medicinais: a necessidade de estudos multidisciplinares. Química Nova, São Paulo, v. 25, n. 3, p. 429-438, 2002.

MADEIRA, N. R.; TEIXEIRA, J. B.; ARIMURA, C. T.; JUNQUEIRA, C. S. Influência da concentração de BAP e $\mathrm{AG}_{3}$ no desenvolvimento in vitro de mandioquinha-salsa. Horticultura Brasileira, Brasília, v. 23, n. 4, p. 982-985, 2005.

MARIMUTHU, S.; KUMAR, R. R. Physiological and biochemical responses of micropropagated tea plants. In Vitro Cellular \& Developmental Biology - Plant, Chesterfield, v. 37, n. 5, p. 618-621, 2001.

MONFORT, L. E. F.; PINTO, J. E. B. P.; BERTOLUCCI, S. K. V.; ROSSI, Z. T. T.; SANTOS, F. M. Efeito do BAP no cultivo in vitro de Ocimum selloi Benth. Revista Brasileira de Plantas Medicinais, Botucatu, v. 14, n. 3, p. 458-463, 2012.

MURASHIGE, T.; SKOOG, F. A revised medium for rapid growth and bioassays with tobacco tissue cultures. Physiologia Plantarum, Lund, v. 15, p. 473-497, 1962.

OLIVEIRA, R. P.; SILVA, S. O. Avaliação da micropropagação comercial em bananeira. Pesquisa Agropecuária Brasileira, Brasília, v. 32, n. 4, p. 415-420, 1997.

PEREIRA, A. M. S.; MORO, J. R.; CERDEIRA, R. M. M.; FRANCA, S. C. Effects of phytoregulators and physiological characteristics of the explants on micropropagation of Maytenus ilicifolia. Plant Cell, Tissue and Organ Culture, London, v. 42, n. 3, p. 295-297, 1995.

PEREIRA-NETTO, A. B. Effect of inhibitors of ethylene biosynthesis and signal transduction pathway on the multiplication of in vitro-grown Hancornia speciosa. Plant Cell, Tissue and Organ Culture, Dordrecht, v. 66, n. 1, p. 1-7, 2001.
PEREIRA-NETTO, A. B.; MCCOWN, B. H.; PHARIS, R. P. Inhibition of growth of microcultured Hancornia speciosashoots by 3 -hydroxylated gibberellins and one of their C-3 deoxy precursors. Plant Cell Reports, New York, v. 21, n. 5, p. 491-496, 2003.

RATHORE, T. S.; DEORA, N. S.; SHEKHAWAT, N. S. Cloning of Maytenus emarginata (Wild.) Ding Hou - a tree of the Indian Desert, through tissue culture. Plant Cell Reports, New York, v. 11, n. 9, p. 449-451, 1992.

RIBAS, L. L. F.; ZANETTE, F.; KULCHETSCKI, L.; GUERRA, M. P. Estabelecimento de culturas assépticas de Aspidosperma polyneuron. Ciência Florestal, Santa Maria, v. 13, n. 1, p. 115-122, 2003.

SÁ, A. J.; LÉDO, A. S.; LÉDO, C. A. S., PASQUAL, M.; SILVA, A. V. C.; SILVA JUNIOR, J. F. Sealing and explant types on the mangaba micropropagation. Ciência e Agrotecnologia, Lavras, v. 36, n. 4, p. 406-414, 2012.

SATO, A. Y.; DIAS, H. C. T.; ANDRADE, L. A.; SOUZA, V. C. Micropropagação de Celtis sp.: controle da contaminação e oxidação. Cerne, Viçosa, v. 7, n. 2, p. 117-123, 2001.

SCHERWINSKI-PEREIRA, J. E.; MATTOS, M. L. T.; FORTES, G. R. L. Bactérias endofíticas contaminantes em explantes de batata micropropagados e antibióticos para o controle in vitro. Pesquisa Agropecuária Brasileira, Brasília, v. 38, n. 7, p. 827-834, 2003.

SHUKOR, A.; AINI, N.; JAINOL, J. E.; YUSOF, A. M.; KADIR, A. M. Defoliation of in vitro shootlets of Azadirachta excelsa (Jack) M. Jacobs: a possible solution. The Malaysian Forester, Kuala Lumpur, v. 71, n. 1, p. 37-44, 2008.

SILVA, F. R.; WISNIEWSKI JUNIOR, A.; CECHINEL FILHO, V.; NUNES, D. S. Chemical composition of essential oil from the bark of Croton cajucara Bentham. Acta Scientiarum. Technology, Maringá, v. 34, n. 3, p. 325-329, 2012.

SUSSEX, I. M. The scientific roots of modern plant biotechnology. The Plant Cell, Waterbury, 20, p. 1189-1198, 2008.VARRICCHIO, M. C. B. N.; ORMELEZ, E. G.; MOREIRA, C. B.; SILVA, S. da; KUSTER, R. M.; LAGE, C. L. S. Cultivo in vitro de Euphorbia tirucalli (aveloz), avaliação da constituição química do látex, em diferentes condições de cultivo, e teste de atividade larvicida e juvenilizante em Aedes aegypti. Biofar: Revista de Biologia e Farmácia, João Pessoa, v. 2, n. 1, p. 1-14, 2008.

VIDAL, F. R.; DINIZ, J. D. N.; SILVA, F. P. Multiplicação in vitro de plantas juvenis de mamoeiro Pesquisa Agropecuária Tropical, Goiânia, v. 43, n. 1, p. 64-70, 2013.

ZONTA, E. P.; MACHADO, A. A. SANEST - sistema de análise estatística para microcomputadores. Pelotas: UFPel, SEI, 1984. $138 \mathrm{p}$. 